\title{
ANALISIS KESESUAIAN LAHAN UNTUK PERTANIAN PANGAN BERKELANJUTAN DI KABUPATEN MAHAKAM HULU
}

\author{
Zulkarnain $^{1}$, RM. Nur Hartanto' \\ ${ }^{1)}$ Program Studi Agroekoteknologi, Fakultas Pertanian Universitas Mulawarman, \\ Indonesia. \\ Jalan Pasir Balengkong, Kampus Gunung Kelua, Samarinda, Kalimantan Timur, \\ Indonesia, 75119. Telp: +62541749161, Fax: +62541738341. \\ E-Mail: zulknn@gmail.com
}

\begin{abstract}
ABSTRAK
Analisis Kesesuaian Lahan Untuk Pertanian Pangan Berkelanjutan Di Kabupaten Mahakam Hulu. Keterbatasan sumber daya manusia terutama petani dan infrastruktur yang terbatas menyebabkan sebagian besar lahan di Kabupaten Mahakan Ulu belum dimanfaatkan secara optimal untuk pertanian pangan sehingga masih mengandalkan pangan dari luar.Tujuan penelitian adalah untuk mengetahui potensi lahan pertanian yang dapat ditetapkan sebagai lahan pertanian pangan berkelanjutan berdasarkan pendekatan kesesuaian lahan di Kabupaten Mahakam Ulu.

Data yang dikumpulkan dalam penelitian ini meliputi data-data spasial, yaitu peta topografi, peta penggunaan lahan, peta tanah, peta sistem lahan dan peta pola ruang (RTRW), serta data statistik yaitu data curah hujan. Pengumpulan data kualitas dan karaketeristik lahan juga dilakukan secara langsung di lapangan untuk memvalidasi satuan unit yang dihasilkan pada proses sebelumnya. Analisis kesesuaian lahan dilakukan pada setiap peta satuan lahan. Evaluasi kesesuaian lahan pada studi ini menggunakan metode kualitatif, yaitu menggunakan hukum minimum. Pada metode ini dilakukan pencocokkan (matching) antara kualitas lahan dan karakteristik lahan sebagai parameter dengan kritera kelas kesesuaian lahan yang telah disusun berdasarkan persyaratan penggunaan atau persyaratan tumbuh tanaman atau komoditi yang dievaluasi. Hasil penelitian menunjukan bahwa lahan yang dapat dijadikan sebagai lahan pertanian pangan berkelanjutan di Kabupaten Mahakam Ulu seluas 98.810 ha yang meliputi 11.879 ha lahan untuk pengembangan komoditi padi sawah dan 84.931 ha lahan untuk pengembangan komoditi padi ladang.
\end{abstract}

Kata kunci : Kesesuaian Lahan, Lahan Pertanian Pangan Berkelanjutan.

\begin{abstract}
Analysis of Land Suitability for Sustainable Food Agriculture in Mahakam Hulu Regency. Limited human resources, especially farmers and limited infrastructure, has caused most of the land in Mahakan Ulu Regency has not been used optimally for food agriculture, so food is still relying on from outside. The purpose of this study is to determine the potential of agricultural land that can be determined as sustainable food agriculture land based on the land suitability approach in Mahakam Ulu Regency.

The data collected in this research include spatial data, whichis topographic maps, land use map, map land, map land system and map the patterm space (SPATIAL), as well as statistical data, i.e. precipitation data. Data collection quality and characteristics of the land are also carried out directly in the field to validate the unit of the units produced in the previous process. Land suitability analysis is performed on each of the land units map.

The land suitability evaluation in this study used a qualitative method, which uses minimum law with matching between the land quality and the characteristics as a parameter with the criteria of land suitability classes that have been prepared based on the terms of use or requirements for growing plants or commodities that are evaluated. The results of the land suitability evaluation obtained an appropriate land area for 11. 879 ha of lowland rice and 84.931 ha of up land rice. Land suitability class for both were S3 or marginal suit. The land can be used as a sustainable food agriculture land because this area does not yet have agricultural land that is able to produce food sustainably.
\end{abstract}

Key words : Land Suitability, Sustainability Food Agriculture. 


\section{PENDAHULUAN}

Kabupaten Mahakam Ulu merupakan pemekaran dari Kabupaten Kutai Barat dengan luas mencapai 1,9 juta hektar yang memiliki potensi sumberdaya lahan untuk dapat digunakan sebagai pertanian khususnya tanaman pangan guna menopang kebutuhan primer masyarakat yang diharapkan dapat mendukung ketahanan pangan dan menjadi penopang perekonomian rakyat. Keterbatasan sumberdaya manusia terutama petani dan keterbatasan infrastruktur meyebabkan sebagian besar lahan di Kabupaten Mahakan Ulu belum dimanfaatkan secara optimal untuk pertanian pangan, sehingga pemenuhan kebutuhan bahan pangan masih mengandalkan dari luar daerah.

$$
\text { Penggunaan lahan yang }
$$

berkelanjutan adalah penggunaan lahan yang dapat memenuhi kebutuhan saat ini, dan pada saat yang sama dapat mengkonservasi sumberdaya lahan untuk generasi mendatang. Pada banyak kasus kerusakan tanah sampai memunculkan lahan kritis, faktor utamanya adalah penggunaan lahan yang melebihi daya dukungnya dan mengabaikan kaidahkaidah konservasi tanah dan air dalam pengelolaannya (Nugroho, 2000; Arsyad, 2006). Fisiografi lahan di Kabupaten Mahakam Ulu didominasi oleh pegunungan dan perbukitan yang sangat rentan mengalami degradasi jika salah dalam pengelolaannya. Ditambah lagi, degradasi lahan dapat menyebabkan kerusakan pada sistem DAS Mahakam karena Kabupaten Mahakam Ulu terletak di bagian hulu DAS Mahakam. Oleh sebab itu, ketersediaan informasi mengenai potensi sumberdaya lahan sangat penting di dalam mewujudkan perencanaan penggunaan lahan yang berkelanjutan (Budiarta, 2014).

Arahan pengembangan komoditas pada suatu lahan mencakup perencanaan penggunaan lahan untuk pengembangan komoditas tertentu, termasuk tanaman pangan (Sitorus et al., 2012). Perencanaan penggunaan lahan dapat menggunakan pendekatan analisis kemampuan lahan atau kesesuaian lahan. Analisis kesesuaian lahan untuk pertanian tanaman pangan dilakukan untuk pemetaan sumberdaya lahan dan evaluasi lahan yang dapat ditetapkan sebagai lahan pertanian pangan berkelanjutan melalui kebijakan pemerintah Kabupaten Mahakam Hulu sebagaimana yang diamanatkan dalam Undang-Undang Nomor 41 tahun 2009 tentang Perlindungan Lahan Pertanian Pangan Berkelanjutan. Hal ini dilakukan untuk menghindari konflik pemanfaatan lahan sekaligus melindungi lahan pertanian dari alihfungsi sehingga dapat mendukung ketahanan pangan setempat dan memperkuat ekonomi rakyat (Janti, 2016). Penetapan lahan-lahan pertanian pangan yang potensial juga dapat menjaga ketersediaan lahan untuk pengembangan pertanian pangan dimasa yang akan datang.

Tujuan penelitian ini untuk mengetahui potensi lahan pertanian yang dapat ditetapkan sebagai lahan pertanian pangan berkelanjutan berdasarkan pendekatan kesesuaian lahan di Kabupaten Mahakam Ulu.

\section{METODA PENELITIAN}

\subsection{Tempat dan Waktu}

Kabupaten Mahakam Hulu tahun 2018.

\subsection{Metode Pengumpulan Data}

Data yang dikumpulkan dalam penelitian ini meliputi data-data spasial, yaitu peta topografi, peta penggunaan lahan, peta tanah, peta sistem lahan dan peta pola ruang (RTRW), serta data statistik yaitu 
data curah hujan. Data spasial berupa peta topografi, jenis tanah dan penggunaan selanjutnya ditumpangsusunkan sehingga diperoleh satuan unit lahan. Unit lahan adalah sebidang lahan yang memiliki kondisi sama dalam hal bentuk lahan, jenis tanah, kemiringan lereng, dan penggunaan lahan (Sitorus, 2004). Pengumpulan data kualitas dan karaketeristik lahan juga dilakukan secara langsung di lapangan untuk memvalidasi satuan unit yang dihasilkan pada proses sebelumnya.

\subsection{Metode Analisis Data}

Analisis kesesuaian lahan dilakukan pada setiap peta satuan lahan. Evaluasi kesesuaian lahan adalah membandingkan persyaratan yang diminta oleh tipe penggunaan lahan yang akan diterapkan, dengan sifat-sifat atau kualitas lahan yang dimiliki oleh lahan yang akan digunakan (Hardjowigeno \& Widiatmaka, 2001). Penapisan dilakukan terhadap lahan yang berdasarkan pola ruang termasuk kawasan lindung.

Evaluasi kesesuaian lahan pada studi ini menggunakan metode kualitatif, yaitu menggunakan hukum minimum. Pada metode ini dilakukan pencocokkan (matching) antara kualitas lahan dan karakteristik lahan sebagai parameter dengan kritera kelas kesesuaian lahan yang telah disusun berdasarkan persyaratan penggunaan atau persyaratan tumbuh tanaman atau komoditi yang dievaluasi. Kesimpulan kelas kesesuaian lahan diperoleh dari karakteristik lahan yang memiliki hasil evaluasi terendah (nilai minimum). Komoditi tanaman pangan yang dievaluasi dalam rangka pertanian berkelanjutan di Kabupaten Mahakam Ulu adalah padi sawah tadah hujan dan padi ladang. Persyaratan tumbuh tanaman menggunakan Petunjuk Teknis Evaluasi Lahan Balai Penelitian Tanah (Djainudin et al, 2003).

Tabel 1. Kriteria Evaluasi Lahan Padi Sawah Tadah Hujan.

\begin{tabular}{|c|c|c|c|c|}
\hline \multirow{2}{*}{$\begin{array}{c}\text { Persyaratan Penggunaan } \\
\text { Lahan/Karakteristik Lahan }\end{array}$} & \multicolumn{4}{|c|}{ Kelas Kesesuaian Lahan } \\
\hline & S1 & $\mathbf{S 2}$ & S3 & $\mathbf{N}$ \\
\hline \multicolumn{5}{|l|}{ Temperatur (tc) } \\
\hline \multirow[t]{2}{*}{ Temperatur rata-rata $\left({ }^{\circ} \mathrm{C}\right)$} & $24-29$ & $22-24$ & $18-22$ & $<35$ \\
\hline & & $29-32$ & $32-35$ & $>18$ \\
\hline \multicolumn{5}{|l|}{ Ketersediaan air (wa) } \\
\hline \multirow{2}{*}{ Curah hujan (mm) bulan ke-1 } & $175-500$ & $500-650$ & $650-750$ & $>750$ \\
\hline & & $125-175$ & $100-125$ & $<100$ \\
\hline \multirow[t]{2}{*}{ Curah hujan (mm) bulan ke-2 } & $175-500$ & $500-650$ & $650-750$ & $>750$ \\
\hline & & $125-175$ & $100-125$ & $<100$ \\
\hline \multirow[t]{2}{*}{ Curah hujan $(\mathrm{mm})$ bulan ke-3 } & $175-500$ & $500-650$ & $650-750$ & $>750$ \\
\hline & & $125-175$ & $100-125$ & $<100$ \\
\hline \multirow[t]{2}{*}{ Curah hujan (mm) bulan ke-4 } & $50-300$ & $300-500$ & $500-600$ & $>600$ \\
\hline & & $30-50$ & $<30$ & \\
\hline Kelembaban $(\%)$ & $33-90$ & $30-33$ & $<30>90$ & - \\
\hline \multicolumn{5}{|l|}{ Media perakaran (rc) } \\
\hline Drainase & $\begin{array}{l}\text { Terhambat, } \\
\text { agak terhambat }\end{array}$ & $\begin{array}{l}\text { Agak cepat, } \\
\text { sedang, baik }\end{array}$ & $\begin{array}{c}\text { Sangat } \\
\text { terhambat }\end{array}$ & Cepat \\
\hline Tesktur & $\begin{array}{l}\text { Halus, agak } \\
\text { halus, sedang }\end{array}$ & $\begin{array}{l}\text { Halus, agak } \\
\text { halus, sedang }\end{array}$ & Agak kasar & Kasar \\
\hline Bahan kasar (\%) & $<3$ & $3-15$ & $15-35$ & $>35$ \\
\hline Kedalaman tanah $(\mathrm{cm})$ & $>50$ & $40-50$ & $25-40$ & $<25$ \\
\hline
\end{tabular}




\begin{tabular}{|c|c|c|c|c|}
\hline $\begin{array}{l}\text { Gambut } \\
\text { Ketebalan (cm) } \\
\text { Kematangan } \\
\end{array}$ & $\begin{array}{c}<60 \\
\text { Saprik }\end{array}$ & $\begin{array}{c}60-140 \\
\text { Saprik, hemik }\end{array}$ & $\begin{array}{c}140-200 \\
\text { Hemik, fibrik }\end{array}$ & $\begin{array}{l}>200 \\
\text { fibrik }\end{array}$ \\
\hline \multicolumn{5}{|l|}{ Retensi hara (nr) } \\
\hline KTK liat (cmol) & $>16$ & $\leq 16$ & - & - \\
\hline $\mathrm{pH} \mathrm{H}_{2} \mathrm{O}$ & $5,5-8,2$ & $5, \overline{0}-5,5$ & $<5,0$ & - \\
\hline & & $8,2-8,5$ & $>8,5$ & \\
\hline \multicolumn{5}{|l|}{ Toksisitas (xc) } \\
\hline Salinitas (ds/m) & $<2$ & $2-4$ & $4-6$ & $>6$ \\
\hline \multicolumn{5}{|l|}{ Bahaya sulfidik (xs) } \\
\hline Kedalaman sulfidik $(\mathrm{cm})$ & $>100$ & $75-100$ & $40-75$ & $<40$ \\
\hline \multicolumn{5}{|l|}{ Bahay erosi (eh) } \\
\hline Lereng $(\%)$ & $<3$ & $3-8$ & $8-25$ & $>25$ \\
\hline Bahaya erosi & Sangat rendah & Rendah-sedang & Berat & Sangat berat \\
\hline \multicolumn{5}{|l|}{ Bahaya banjir (fh) } \\
\hline Genangan & $\begin{array}{c}\text { F0-F12, F21, } \\
\text { F22 }\end{array}$ & $\begin{array}{c}\text { F13, F23, F41, } \\
\text { F42 }\end{array}$ & $\begin{array}{l}\text { F14, F24, } \\
\text { F34, F43 }\end{array}$ & $\begin{array}{l}>\mathrm{F} 14 \\
>\mathrm{F} 43\end{array}$ \\
\hline \multicolumn{5}{|l|}{ Penyiapan lahan (lp) } \\
\hline Batuan di permukaan (\%) & $<5$ & $5-15$ & $15-40$ & $>40$ \\
\hline Singkapan batuan $(\%)$ & $<5$ & $5-15$ & $15-25$ & $>40$ \\
\hline
\end{tabular}

Sumber: Djaenudin et al (2003).

Tabel 2. Kriteria Evaluasi Lahan Padi Ladang.

\begin{tabular}{|c|c|c|c|c|}
\hline \multirow{2}{*}{$\begin{array}{c}\text { Persyaratan Penggunaan } \\
\text { Lahan/Karakteristik Lahan }\end{array}$} & \multicolumn{4}{|c|}{ Kelas Kesesuaian Lahan } \\
\hline & S1 & $\mathrm{S2}$ & S3 & $\mathbf{N}$ \\
\hline \multicolumn{5}{|l|}{ Temperatur (tc) } \\
\hline Temperatur rata-rata $\left({ }^{\circ} \mathrm{C}\right)$ & $24-29$ & $\begin{array}{l}22-24 \\
29-32 \\
\end{array}$ & $\begin{array}{l}18-22 \\
32-35\end{array}$ & $\begin{array}{l}<35 \\
>18\end{array}$ \\
\hline \multicolumn{5}{|l|}{ Ketersediaan air (wa) } \\
\hline Curah hujan $(\mathrm{mm})$ bulan ke-1 & $50-400$ & $400-550$ & $550-650$ & $\begin{array}{l}>650 \\
<50\end{array}$ \\
\hline Curah hujan (mm) bulan ke-2 & $100-400$ & $\begin{array}{c}400-550 \\
75-100\end{array}$ & $\begin{array}{c}550-650 \\
50-75\end{array}$ & $\begin{array}{l}>650 \\
<50\end{array}$ \\
\hline Curah hujan (mm) bulan ke-3 & $100-400$ & $\begin{array}{c}400-550 \\
75-100\end{array}$ & $\begin{array}{l}550-650 \\
50-75\end{array}$ & $\begin{array}{l}>650 \\
<50\end{array}$ \\
\hline Curah hujan (mm) bulan ke-4 & $50-400$ & $\begin{array}{l}400-550 \\
<50\end{array}$ & $550-650$ & $>650$ \\
\hline Kelembaban $(\%)$ & $33-90$ & $30-33$ & $<30>90$ & - \\
\hline \multicolumn{5}{|l|}{ Media perakaran (rc) } \\
\hline Drainase & $\begin{array}{c}\text { Baik, sedang, agak } \\
\text { cepat }\end{array}$ & - & $\begin{array}{l}\text { Terhambat, } \\
\text { sangat } \\
\text { terhambat }\end{array}$ & Cepat \\
\hline Tesktur & $\begin{array}{l}\text { Halus, agak halus, } \\
\text { sedang }\end{array}$ & & Agak kasar & Kasar \\
\hline Bahan kasar (\%) & $<3$ & $3-15$ & $15-35$ & $>35$ \\
\hline Kedalaman tanah $(\mathrm{cm})$ & $>50$ & $40-50$ & $25-40$ & $<25$ \\
\hline \multicolumn{5}{|l|}{ Gambut } \\
\hline Ketebalan $(\mathrm{cm})$ & $<60$ & $60-140$ & $140-200$ & $>200$ \\
\hline Kematangan & Saprik & Saprik, hemik & Hemik, fibrik & fibrik \\
\hline \multicolumn{5}{|l|}{ Retensi hara (nr) } \\
\hline KTK liat (cmol) & $>16$ & $\leq 16$ & - & - \\
\hline $\mathrm{pH} \mathrm{H}_{2} \mathrm{O}$ & $5,5-7,5$ & $5, \overline{0}-5,5$ & $<5,0$ & - \\
\hline & & $7,5-7,9$ & $>7,9$ & \\
\hline \multicolumn{5}{|l|}{ Toksisitas (xc) } \\
\hline Salinitas $(\mathrm{ds} / \mathrm{m})$ & $<2$ & $2-4$ & $4-6$ & $>6$ \\
\hline \multicolumn{5}{|l|}{ Bahaya sulfidik (xs) } \\
\hline Kedalaman sulfidik $(\mathrm{cm})$ & $>75$ & $50-75$ & $30-50$ & $<30$ \\
\hline Bahay erosi (eh) & & & & \\
\hline
\end{tabular}




\begin{tabular}{lcccc}
\hline $\begin{array}{l}\text { Lereng (\%) } \\
\text { Bahaya erosi }\end{array}$ & $\begin{array}{c}< \\
\text { Sangat rendah }\end{array}$ & $\begin{array}{c}8-16 \\
\text { Rendah-sedang }\end{array}$ & $\begin{array}{c}16-30 \\
\text { Berat }\end{array}$ & $\begin{array}{c}>30 \\
\text { Sangat berat }\end{array}$ \\
\hline $\begin{array}{l}\text { Bahaya banjir (fh) } \\
\text { Genangan }\end{array}$ & - & F11 & F12-F13 & $>$ F13 \\
\hline $\begin{array}{l}\text { Penyiapan lahan (lp) } \\
\text { Batuan di permukaan (\%) }\end{array}$ & $<5$ & $5-15$ & $15-40$ & $>40$ \\
$\quad$ Singkapan batuan (\%) & $<5$ & $5-15$ & $15-25$ & $>25$ \\
\hline
\end{tabular}

Sumber: Djaenudin, et al. (2003).

\section{HASIL PENELITIAN DAN PEMBAHASAN}

\subsection{Kondisi Umum Wilayah Studi}

Curah hujan di wilayah studi cukup tinggi yaitu berkisar antara 2.600-3.600 $\mathrm{mm} /$ tahun dengan bulan basah sebanyak 8-9 bulan. Ketersediaan air untuk pertanian di Kabupaten Mahakam Ulu masih sangat tergantung pada curah hujan karena belum tersedinya sarana dan prasarana irigasi sehingga pengembangan komoditas padi sawah tandah hujan lebih diutamakan dibandingkan sawah irigasi. Namun demikian, secara hidrologi terdapat potensi sumberdaya air di Kabupaten Mahakam Ulu yang dapat dikembangkan untuk irigasi pertanian.

Elevasi lahan di wilayah Kabupaten Mahakam Ulu berkisar antara 50 - > 2000 mdpl. Kelas lereng 15-25 \% (agak curam) dan 25-40 \% (curam) adalah kelas lereng yang dominan di wilayah studi dimana persentasenya mencapai $46 \%$. Tanah yang terdapat di Kabupaten Mahakam Ulu merupakan jenis tanah yang umum ditemui di wilayah tropika humida. Tanah terbentuk akibat pengaruh faktor-faktor pembentuk tanah seperti bahan induk, iklim, topografi, vegetasi dan waktu. Jenis tanah yang terdapat di Kabupaten Mahakam Ulu menurut Soil Taxonomi (USDA) adalah ordo Ultisol, Inceptisol, Entisols dan sebagian kecil Mollisols dan Spodosols.

\subsection{Evaluasi Kesesuaian Lahan}

Hasil evaluasi kesesuaian lahan diperoleh lahan yang sesuai untuk padi sawah seluas 11.879 ha dan padi ladang seluas 84.931 ha. Kelas kesesuaian lahan untuk padi sawah berada pada kelas S3, begitu juga dengan padi ladang yang berada pada kelas S3. Peta kesesuaian lahan padi sawah dan peta kesesuaian lahan padi ladang berturut-turut disajikan pada Gambar 1 dan Gambar 2.

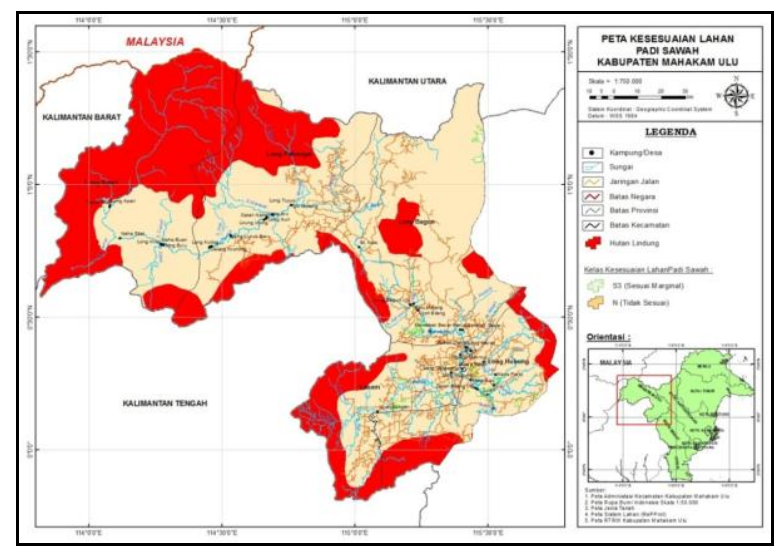

Gambar 1. Peta Kesesuaian Lahan Padi Sawah. 


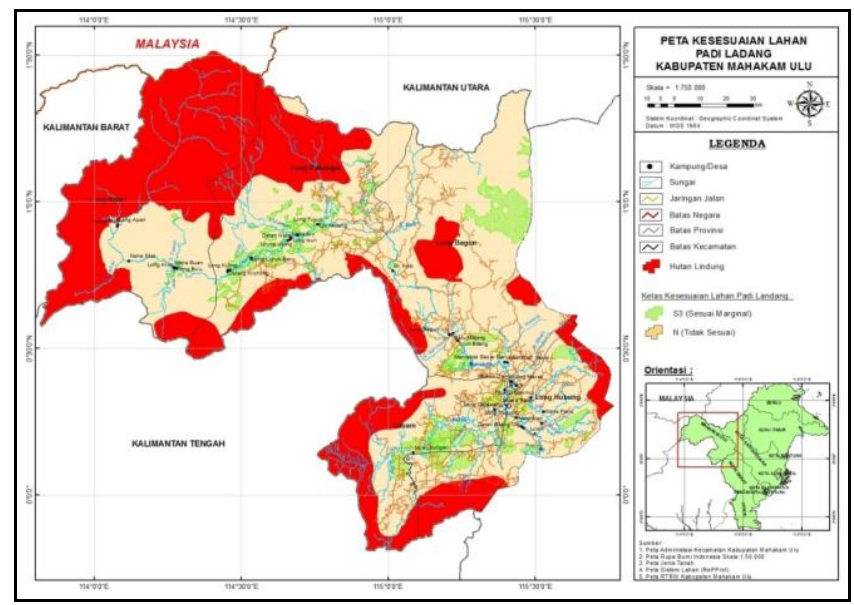

Gambar 2. Peta Kesesuaian Lahan Padi Ladang.

Kelas kesesuaian lahan S3 atau lahan sesuai marginal menunjukkan bahwa terdapat faktor pembatas pertumbuhan tanaman yang cukup berat yang mempengaruhi produktivitas tanaman secara signifikan, yaitu retensi hara dan bahaya banjir untuk komoditi padi sawah; retensi hara dan bahaya erosi untuk komoditi padi ladang. Retensi hara pada lokasi studi disebabkan $\mathrm{pH}$ tanah yang masam. Pada $\mathrm{pH}$ masam, kelarutan aluminium menjadi tinggi dan mengikat senyawa fospor sehingga menurunkan jumlah fospor tersedia di dalam tanah (Wijanarko dan Taufik, 2004). Hal ini dapat menyebabkan tanaman mengalami defisiensi unsur hara fospor sehingga dapat mengganggu pertumbuhan dan produksi tanaman. Lahan yang memiliki faktor pembatas $\mathrm{pH}$ tanah masih dapat ditingkatkan kelas kesesuaiannya menjadi S2 dengan pemberian bahan amelioran yaitu kapur. Tindakan pengapuran termasuk pada tingkat pengelolaan rendah sampai sedang sehingga dianggap masih dapat diaplikasikan di wilayah studi.

Bahaya banjir ditemukan pada lahan yang berada di pinggiran Sungai Mahakam seperti di Kecamatan Long Hubung dan Kecamatan Laham. Berdasarkan informasi yang diperoleh dari warga setempat bahwa kejadian banjir akibat meluapnya Sungai Mahakam dapat terjadi dengan intensitas yang cukup tinggi dengan tinggi genangan $>1 \mathrm{~m}$ dan lama genangan lebih dari satu hari. Walaupun tanaman padi sawah merupakan tanaman yang toleran terhadap genangan, namun banjir selama 3 hari berturut-turut dapat menurunkan produksi sebesar 23,4 dan semakin meningkat dengan bertambahnya waktu genangan (Sulistyono et al, 2012). Lahan yang memiliki faktor pembatas bahaya banjir masih dapat ditingkatkan kelas kesesuainnya menjadi S2, yaity dengan pembuatan tanggul dan/atau saluran drainase. Perbaikan yang dibutuhkan untuk meningkatkan kelas kesesuaian lahan tersebut termasuk ke dalam tingkat pengelolaan/manajemen sedang sehingga untuk pelaksanaannya dibutuhkan bantuan dari pemerintah.

Lahan dengan faktor pembatas bahaya erosi untuk komoditi padi ladang adalah lahan yang berada pada kelas kemiringan 16-30 \%. Luas lahan ini sekitar $30 \%$ dari luas lahan yang sesuai marginal untuk komoditi padi ladang. Faktor pembatas bahaya erosi masih dapat diperbaiki dengan menerapkan teknologi konservasi tanah dan air sehingga kelas kesesuaian lahan 
potensialnya dapat ditingkatkan menjadi S2. Sistem pertanaman lorong merupakan teknik konservasi vegetatif yang telah terbukti efektif mengendalikan erosi dan aliran permukaan (runoff), kehilangan hara, meningkatkan produktivitas tanah dan tanaman, efisien dari segi biaya (Ariani dan Haryati, 2018). Teknologi ini dapat diadopsi oleh petani di Kabupaten Mahakam Ulu yang memiliki keterbatasan sumberdaya dan aksesibilitas ke lahan pertanian yang masih rendah. Sistem penanaman dalam lorong pada lahan kering mampu mengurangi erosi tanah sampai dengan $40 \%$ (Islami dan Utomo, 2006). Selain itu, biomassa yang dihasilkan dari tanaman lorong dapat meningkatkan kandungan bahan organik tanah dan unsur-unsur hara. Tingkat pengelolaan lahan untuk penanaman dalam lorong termasuk tingkat pengelolaan rendah sehingga dapat diaplikasikan dengan sumberdaya yang ada.

\subsection{Lahan Pertanian Pangan Berkelanjutan}

Pengembangan lahan pertanian pangan berkelanjutan diarahkan pada lahan yang memiliki kelas kesesuaian lahan S3 untuk komoditi padi sawah dan lahan yang memiliki kelas kesesuaian lahan S3 untuk komoditi padi ladang yang belum digunakan untuk lahan budidaya tanaman perkebunan. Hasil evaluasi kesesuaian lahan menunjukkan bahwa baik lahan yang sesuai untuk padi sawah maupun lahan yang sesuai untuk padi ladang dapat dijadikan sebagai lahan pertanian pangan berkelanjutan. Lahan pertanian pangan berkelanjutan di Kabupaten Mahakam Ulu ini masih berupa lahan potensial, bukan lahan pertanian aktual karena belum terdapat lahan pertanian pangan yang diusahakan secara menetap dengan hamparan yang cukup sebagai lahan pertanian pangan berkelanjutan. Berikut sebaran kesesuaian lahan yang dapat dijadikan acuan untuk pengembangan lahan pertanian pangan berkelanjutan di Kabupaten Mahakam Ulu (Tabel 3).

Tabel 3. Lahan Cadangan Pertanian Pangan Berkelanjutan di Kabupaten Mahakam Ulu berdasarkan Kelas Kesesuaian Lahan.

\begin{tabular}{|c|c|c|c|c|}
\hline \multirow{2}{*}{ No } & \multirow{2}{*}{ Kecamatan } & \multicolumn{2}{|c|}{$\begin{array}{l}\text { Lahan Cadangan Pertanian Pangan } \\
\text { Berkelanjutan }\end{array}$} & \multirow{2}{*}{$\begin{array}{c}\text { Jumlah } \\
\text { (ha) }\end{array}$} \\
\hline & & Padi Sawah (ha) & Padi Ladang (ha) & \\
\hline 1 & Long Hubung & 4.510 & 14.599 & 19.109 \\
\hline 2 & Long Bagun & 4.703 & 24.846 & 29.549 \\
\hline 3 & Long Pahangai & 81 & 25.934 & 26.015 \\
\hline 4 & Long Apari & - & 2.402 & 2.402 \\
\hline \multirow[t]{2}{*}{5} & Laham & 2.585 & 17.150 & 19.735 \\
\hline & Jumlah & 11.879 & 84.931 & 96.810 \\
\hline
\end{tabular}

Sumber : hasil analisis

Keterangan : kelas kesesuaian lahan S3

Padi ladang merupakan komoditi utama penghasil bahan pangan di Kabupaten Mahakam Ulu. Budidaya padi ladang menggunakan sistem perladangan berpindah. Budidaya tanaman pangan di wilayah studi masih bersifat konvensional yaitu belum menerapkan teknologi pertanian sehingga produktivitas lahan rendah. Sistem perladangan berpindah dengan waktu pergiliran 10 tahun dan pada lahan yang sama digunakan selama dua kali (dua tahun) berutur-turut. Dengan pola perladangan berpindah tersebut, maka alokasi lahan untuk padi ladang menjadi lima kali lebih besar dibandingkan jika 
dilakukan secara menetap. Tantangan budidaya padi ladang ke depan semakin meningkat dengan munculnya perubahan iklim yang menyebabkan anomali iklim dan cuaca sehingga waktu tanam padi ladang semakin tidak menentu. Selain itu, adanya kegiatan pemanfaatan lahan lainnya seperti perkebunan dapat mengurangi luas lahan yang dapat dikelola untuk perladangan berpindah.

\section{KESIMPULAN}

Hasil penelitian menunjukan bahwa lahan yang dapat dijadikan sebagai lahan pertanian pangan berkelanjutan di Kabupaten Mahakam Ulu seluas 98.810 ha yang meliputi 11.879 ha lahan untuk pengembangan komoditi padi sawah dan 84.931 ha lahan untuk pengembangan komoditi padi ladang.

\section{DAFTAR PUSTAKA}

Ariani, R., Haryati M. (2018). Sistem Alley Cropping: Analisis SWOT dan Strategi Implementasinya di Lahan Kering DAS Hulu. Jurnal Sumberdaya Lahan. 12(1)

Arsyad, S. (2006). Konservasi Tanah dan Air Edisi ke 2. Bogor: IPB Press.

Budiarta, IG. (2014). Analisis Kemampuan Lahan Untuk Arahan Penggunaan Lahan pada Lereng Timur Laut Gunung Agung Kabupaten Karangasem-Bali. Media Komunikasi Geografi. 15(1), 19-32.

Djaenudin, D. Marwan, H., Subaguo H., Hidayat A. (2003). Petunjuk Teknis Evaluasi Lahan untuk Komoditas Pertanian. Bogor: Balai Penelitian Tanah.
Hardjowigeno, S. Widiatmaka. (2001). Kesesuaian Lahan dan Perencanaan Tata Guna Lahan. Bogor: Fakultas Pertanian IPB.

Islami, T. Utomo, WH. (2006). Limpasan Permukaan dan Erosi Tanah Setelah Sepuluh Tahun Menggunakan Sistem Tanaman Lorong. Buana Sains .6(1), 51-58.

Janti, I.J. (2016). Perlindungan Lahan Pertanian Pangan Berkelanjutan Guna Memperkokoh Ketahanan Pangan Wilayah (Studi di Kabupaten Bantul, Daerah Istimewa Yogyakarta). Jurnal Ketahanan Nasional. 22(1), 1-21.

Nugroho, P.S. (2000). Minimalisasi Lahan Kritis Melalui Pengelolaan Sumberdaya Lahan dan Konservasi Tanah dan Air Secara Terpadu. Jurnal Teknologi dan Lingkungan. 10 (10), 73-82.

Sitorus, R.P. (2004). Evaluasi Sumberdaya Lahan. Bandung: Tarsito.

Sitorus, R.P., Jalaluddin, M., Panuju, D.R. (2012). Analisis Kesesuaian dan Ketersediaan Lahan Serta Arahan Pengembangan Komoditas Pertanian di Kabupaten Kepulauan Meranti Provinsi Riau. J. Tanah Lingk. 14(2), 45-55.

Sulistyono, E., Suwarno, Lubis, I., Triwidiyati. (2012). Pengaruh Umur Tanaman dan Lama Banjir Terhadap Pertumbuhan dan Produksi Galur-Galur Padi Sawah. J. Agrivor. 5(2), 133-135.

Wijanarko, A., Taufik, A. (2004). Pengelolaan Kesuburan Lahan Kering Masam untuk Tanaman Kedelai. Bul. Palawija. No. 7 \& 8: 39-50. 